\title{
Seasonal use of Amazon floodplains BY THE TUCUXI Sotalia FLUVIATILIS (GeRVAIS 1853), in the Central Amazon, Brazil
}

\author{
Cláudia Faustino ${ }^{1, *}$ and Vera M. F. da Silva ${ }^{2}$
}

\begin{abstract}
Aвsтract: The riverine tucuxi, Sotalia fluviatilis (Gervais, 1853), inhabits an aquatic environment that changes dramatically along the year. The marked annual floods impose a seasonal rhythmicity on the wildlife on these floodplains. The present study provides an insight on tucuxi seasonal use of floodplain, use of area, group size and the occurrence of calves or juveniles within Mamirauá Reserve, Brazilian Amazon. Tucuxis occur year-round in Mamirauá with a mean number of sightings per monthly survey of 3.8. The fluctuating water level in this floodplain influenced tucuxi use of area by allowing or preventing access to water bodies, and influencing its prey movements. The highest encounter rate recorded in the Reserve, for all surveys combined, was 114.3 tucuxis per $\mathrm{km}$ (mean $=24.8$ per $\mathrm{km}$ ) with clear tucuxi preference for deep channels with high turbulence and productivity, where prey density is high. Tucuxis were scattered throughout the channels but avoided the lake Mamirauá. Groups of one to 30 tucuxis were recorded, with $91 \%$ of groups comprising one to six dolphins (mean $=3.3$ ). Group size showed significant differences among the five systems studied across visual surveys, between years within Mamirauá but not among months. Tucuxi calves or juveniles were recorded year-round.
\end{abstract}

Resumo: O tucuxi ribeirinho, Sotalia fluviatilis (Gervais, 1853), habita um meio que varia drasticamente ao longo do ano. As grandes cheias anuais induzem uma ritmicidade sazonal à vida selvagem destas várzeas. O presente estudo, desenvolvido na Reserva Mamirauá, Amazônia brasileira, visa contribuir para o conhecimento do uso sazonal da várzea pelo tucuxi, seu uso de área, tamanho de grupo e ocorrência de crias ou juvenis. O tucuxi ocorre durante todo o ano no sistema Mamirauá, com um número médio de avistamentos por levantamento mensal de 3.8. A variação no nível do rio nesta região influencia a presença do tucuxi, permitindo ou bloqueando o seu acesso a cursos de água, e influenciando a mobilidade das suas presas. O maior número de tucuxi por km registado na reserva, para todos os levantamentos analisados juntos, foi 114.3 tucuxis por $\mathrm{km}$ (média $=24.8$ por $\mathrm{km}$ ), com uma clara preferência destes golfinhos por canais fundos, de pouca turbulência e elevada produtividade, onde a densidade de presas é elevada. O tucuxi se distribui ao longo dos canais, mas evita o lago Mamirauá. Foram encontrados grupos de um a 30 tucuxis, $91 \%$ contendo de um a seis golfinhos (média = 3.3). O tamanho de grupo revelou diferenças significativas entre os cinco sistemas estudados, entre anos em Mamirauá, mas não entre meses. Foram observadas crias ou juvenis ao longo do ano no sistema Mamirauá.

Keywords: Cetacea, tucuxi, Sotalia fluviatilis, Brazil, Amazon, floodplain, seasonality, use of area, group size.

\section{Introduction}

The tucuxi Sotalia fluviatilis (Gervais, 1853) is the only delphinid (family Delphinidae) living entirely in freshwater (Martin, 1990; Cunha et al., 2005). The taxonomic status of Sotalia has been controversial for more than a century (for review see da Silva and Best, 1994; Cunha et al., 2005; Caballero et al., 2007). The current convention is to recognize two separate species: Sotalia guianensis (Van Bénéden, 1864) for the marine individuals, and Sotalia fluviatilis (Gervais, 1853) for riverine dolphins (Monteiro-Filho et al., 2002; Cunha et al., 2005; Caballero et al., 2007). Monteiro-Filho et al. (2002) recognized two separate species based on a tridimensional morphometric analysis of the skull, and Cunha et al. (2005) found the two species to be clearly separated on the basis of distribution, morphology and genetics, recommending that $S$. fluviatilis should be included in the category of riverine dolphins for conservation management purposes. More recently, Caballero et al. (2007) proposed the common name "costero" for the coastal species and accepted the previously proposed "tucuxi" for the riverine species, based on genetic, morphological and ecological evidences.

Sotalia fluviatilis is endemic to the Amazon River drainage area, ranging in Brazil from Belém through the main tributaries of the Amazon basin (da Silva and Best, 1994). It can be found in the main channels as well as in larger lakes where access is not limited by a narrow and/or shallow channel (da Silva and Best, 1994; 1996). Relatively little is known of this species, classified by the World Conservation Union (IUCN) as Data Deficient (IUCN, 2004). An evident consistency between many reported observations is the fact that tucuxi does not occur randomly along waterways (Magnusson et al., 1980, Martin et al., 2004). Physical features of the rivers are clearly important to the ecology of tucuxi and boto, Inia geoffrensis, a sympatric river dolphin (Martin et al., 2004). The range of the annual floods of the Amazon River system varies up to $15 \mathrm{~m}$, with an important impact on the wildlife (Ayres, 1995). This marked water dynamics shapes the landscape and dominates the ecology of the floodplains, imposing a seasonal rhythmicity to both fauna and flora (Mamirauá, 199633).

\footnotetext{
${ }^{1}$ Faculdade de Ciências do Mar e Ambiente, Universidade do Algarve, Campus de Gambelas, 8005-139 Faro, Portugal.

${ }^{2}$ Laboratório de Mamíferos Aquáticos, Instituto Nacional de Pesquisas da Amazônia, CP 478, 69011-790 Manaus, Amazonas, Brazil. Corresponding author, e-mail: claudia.sea@gmail.com.

${ }^{3}$ Mamirauá (1996) Mamirauá management plan. Sociedade Civil Mamirauá (SCM), National Council for Scientific \& Technological Development (CNPq), Environmental Protection Institute of the State of Amazonas (IPAAM). Brazil.
} 
The large seasonal fluctuation in the river level influences considerably the areas used by tucuxis as they enter lake systems during the rising and high water level, but will leave the area as the water levels recede, thus avoiding being entrapped (Klinowska, 1991; da Silva and Best, 1994).

This paper presents information on tucuxi seasonal use of floodplain, its use of area, group size and occurrence of calves and juveniles within Mamirauá Sustainable Development Reserve, Brazil. Data were collected as part of the long-term project Projeto Boto, carried out since 1994.

\section{Material and Methods}

\section{Study area}

The Mamirauá Sustainable Development Reserve is situated at the confluence of the Japurá and Solimões Rivers, two large white-water (sediment-rich) tributaries of the Amazon River, located at $03^{\circ} 20^{\prime} \mathrm{S}, 64^{\circ} 54^{\prime} \mathrm{W}$ (Figure 1). This Reserve comprises $11240 \mathrm{~km}^{2}$ of river floodplain, most of it forested, which was given protection from commercial resource exploitation in 1990.

The water level in the Amazon varies as a consequence of the rain with a minimum and maximum changing annually and regionally with amplitude of $11-15 \mathrm{~m}$. Around Mamirauá Reserve, Japurá and Solimões Rivers have a width of about $1000 \mathrm{~m}$ and have numerous small channels and lakes. During the low-water period sandbanks emerge creating smaller channels, and many of the small water bodies dry out. Around the Mamirauá Reserve, water levels peak in May and June, and reach their lowest levels between September and early November. The main Mamirauá channel is particularly deep, and retains water even when isolated from the river, although during low water many channels and lakes, including the entrance of the system, become totally cut off and eventually dry out.

The main study area within the Mamirauá Reserve, called Mamirauá system, comprises some $400 \mathrm{~km}^{2}$ of floodplain, an area which is inundated for about six months of the year, approximately from March to August. The Mamirauá system has $36 \mathrm{~km}$ of continuous waterways to which most of the smaller channels and lakes within it are linked during high water; its largest water body is the Mamirauá Lake $(10 \mathrm{~km}$ long, maximum width of $400 \mathrm{~m})$. Around Mamirauá system there are several other lakes systems such as the Amanã, Jacaré and Jarauá lake systems, these also included in this study.

\section{Data collection}

The present study was based on data recorded between November 1994 and August 2003 within Mamirauá Reserve and on large rivers and major lakes systems around it - Japurá/Solimões River; Jarauá, Amanã, Jacaré and Mamirauá lakes.

Data were not evenly collected through time and space. Data were collected daily within Mamirauá system and Japurá/ Solimões River, but only periodically (usually once or twice a month) in the remaining three lake systems (Table 1), and three independent methods were used:

i) One-day surveys, daily within Mamirauá and periodically in Japurá/ Solimões River; Jarauá, Amanã and Jacaré lakes (daily field data collection from a $4.8 \mathrm{~m}$ aluminium boat with two or three observers looking for dolphins and stopping for observation and data collection each time a sighting was made); ii) standardized visual surveys within Mamirauá system (bi-weekly or monthly surveys from a $4.8 \mathrm{~m}$ aluminium boat with four observers on board; surveys carried at a constant speed, always along the same track and at the same time of day); and iii) seasonal surveys carried out three times in 1999 within Mamirauá Reserve and Japurá

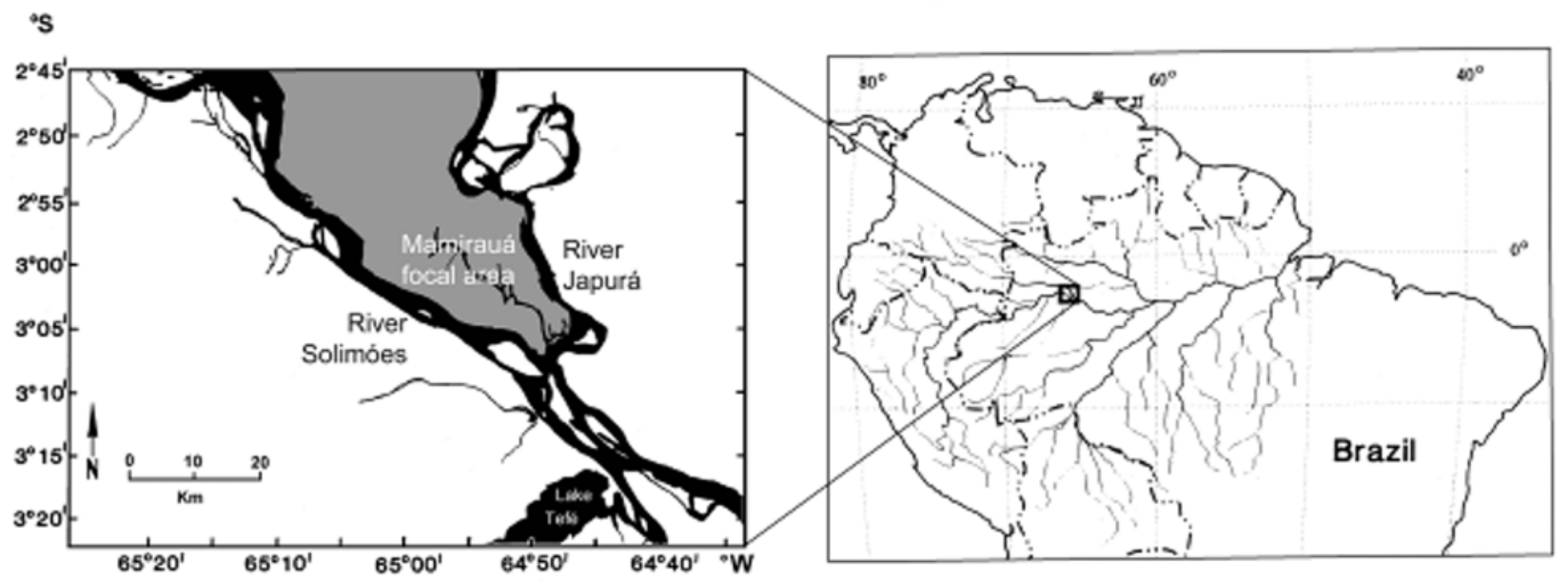

Figure 1. The study location: shaded grey area is flooded habitat of the Mamirauá Sustainable Development Reserve focal area, and areas in white show non-flooded areas. The waterway, shown in black in the shaded area, is the main study area - Mamirauá system, the $30 \mathrm{~km}$ channel with Lake Mamirauá at its northern end. 
River (strip and line transects carried out on board a $17 \mathrm{~m}$ riverboat, with six observers placed in a platform ca. $7 \mathrm{~m}$ above water level). For more detail on the methodology see da Silva and Martin (2000), and Martin and da Silva (2004).

In order to standardize data, when studying use of floodplain and occurrence of calves or juveniles within Mamirauá not all data were used; only standardized visual surveys (ii)) that followed strict criteria (coverage of all study area, reliability and number of observers, and minimum time of survey) were considered. Data collected by all three methods were used for the group size analyses. Sightings within the Mamiraua system were allocated to one of 46 zones, from the head of Mamirauá Lake to the confluence with the Japurá River (Table 2), and analyzed as an indicator for preference in use of area. These zones were equally surveyed but not of equal size so animal encounter rate was estimated by dividing the number of tucuxis sighted in a zone by the length of water channel it covered.

An encounter with a group of tucuxis (comprising one or more animals) during the course of a survey was defined as a 'sighting'. Data recorded included date, time, place, number of animals and group structure. A 'group' was an aggregation of dolphins of any age within visual range of the survey team and usually engaged in a same general activity or behavior. Animals whose body length was estimated to be less than two thirds than adults were noted as calves or juveniles.

\section{Results}

\section{Seasonal use of floodplain}

A total of 583 tucuxi sightings were recorded within the Mamirauá system and plotted with the variation of water level in that region (Figure 2). Tucuxis were observed year-round within Mamirauá system. The mean number of sightings per standardized monthly survey $(i i))$ was $3.81(\mathrm{SE}=0.30$, mode $=2, \mathrm{n}=84)$. A significant increase in the number of tucuxi sightings per survey occurred from October to November and from December to January, at the same time as the dry season ended and water level started to increase. On the other hand, the number of such sightings decreased significantly from March to May, when water levels are reaching their annual peak.

The null hypothesis of equal distribution of tucuxi between months was rejected $\left(\mathrm{F}_{(11,72)}=5.608, \mathrm{p}<\right.$ $0.001)$, demonstrating significant differences in the seasonal use of floodplain by tucuxi. A Bonferroni test $(\mathrm{MS}=4.766, \mathrm{df}=72)$ revealed two groups of months that differed significantly from each other when looking at the mean number of tucuxi sightings per month; these were January, February, March, April, August, November, and December (Group $\alpha$ ) and May, June, July, September, and October (Group $\beta$ ). Group $\alpha$ from the Bonferroni test showed months with higher tucuxi sightings (mean $=4.89$ ), and group $\beta$ gathered months with least sightings per month $($ mean $=1.85)$.

The highest mean number of tucuxy sightings per survey (mean $=0.86$ ) was recorded in January, when the water averages $7.88 \mathrm{~m}$ high; the lowest was noted in October (mean 1.50), when water level averages $3.0 \mathrm{~m}$.

\section{Use of area}

Striking differences in the encounter rate of tucuxi were found between zones within the Mamirauá system, along the monthly surveys (ii), $\mathrm{n}=580$ ) (Figure 3).

Along the 46 zones considered, from the head of Mamirauá Lake to the confluence with Japurá River, tucuxis were seen in encounter rates that ranged from zero to 114.3 tucuxis per $\mathrm{km}$, with mean of 24.8 per $\mathrm{km}$ $(\mathrm{SE}=3.73$, mode $=20, \mathrm{n}=46)$. Eight of these zones showed high tucuxi encounter rate (defined as two times larger than the mode, meaning $>40$ per $\mathrm{km}$ ). The distance between the outermost and innermost zone was $20.8 \mathrm{~km}, 57.6 \%$ of the Mamirauá system; the innermost zone was located at nearly $10 \mathrm{~km}$ from the head of the Mamirauá Lake.

\section{Group size}

Group size data (gathered from all the three survey methods, both within Mamirauá and adjacent lake and river system) (Table 3) show tucuxi form groups of one to 30 animals. Ninety-one percent of groups comprised six dolphins and mean group size was $3.31(\mathrm{SE}=0.04$, mode $=2, \mathrm{n}=2677$ ) (Figure 4 ).

Table 1. Number of surveys with tucuxi sightings recorded for each of the five systems considered in this study (Mamirauá, Amanã, Jacaré and Jarauá lakes, Japurá/ Solimões rivers), and time period of such surveys (from start date to end date).

\begin{tabular}{lccccc}
\hline \hline & & \multicolumn{5}{c}{ SYSTEM } \\
& MAMIRAUÁ & AMANÃ & JACARÉ & JARAUÁ & JAPURÁ/ SOLIMÕES \\
\hline \hline No. surveys & 515 & 15 & 9 & 21 & 213 \\
Start date & 1994 & 1999 & 1998 & 1996 & 1996 \\
End date & 2003 & 2001 & 2001 & 2001 & 2001 \\
\hline \hline
\end{tabular}


Table 2. Description of the 46 zones defined within Mamirauá system, from the head of Mamirauá Lake to the confluence with the Japurá River.

\begin{tabular}{|c|c|c|c|}
\hline \multirow[b]{2}{*}{ CODE } & \multicolumn{3}{|c|}{ MAMIRAUÁ ZONES } \\
\hline & NAME & LENGTH (M) & PHYSICAL CHARACTERISTIC(S) \\
\hline 1 & Cabeceira & 1000 & Head of main lake; innermost zone \\
\hline 2 & Above Boca Acacio & 1100 & Wide lake \\
\hline 3 & Boca Acacio & 490 & Confluence of channels; wide \\
\hline 4 & Btw Acacio \& Saracura & 780 & Wide; shallow \\
\hline 5 & Boca Saracura & 350 & Confluence of channels; wide \\
\hline 6 & Btw Saracura \& Miua & 1710 & Entrance of main lake \\
\hline 7 & Ressaca Miua & 250 & Shallow, low current \\
\hline 8 & TRE + TRE to Anagua & 1060 & Narrow; low current \\
\hline 9 & Boca Anagua & 260 & Confluence of channels \\
\hline 10 & Btw Anagua \& Onca & 700 & River channel; low current \\
\hline 11 & Boca Onca & 100 & Confluence of channels; low current \\
\hline 12 & Btw Onca \& Moura & 1220 & River channel \\
\hline 13 & Boca Moura & 100 & Confluence of channels; low current \\
\hline 14 & Btw Moura \& Iuiri & 540 & River channel; wide \\
\hline 15 & Iuiri & 150 & Confluence of channels; with meeting of waters \\
\hline 16 & Ressaca Iuiri & 1820 & Wide channel; low current \\
\hline 17 & Btw Iuiri \& Varador Rato & 2580 & Wide channel; wide \\
\hline 18 & Varador Rato & 100 & Confluence of channels; narrow \\
\hline 19 & Btw Varador Rato \& Cano Rato & 1070 & River channel; narrow \\
\hline 20 & Cano Rato & 100 & Confluence of channels \\
\hline 21 & Btw Cano Rato \& FLU & 1900 & River channel; narrow \\
\hline 22 & FLU & 170 & Wide channel; with meeting of waters \\
\hline 23 & Btw FLU \& Zeca Pontes & 950 & River channel; wide \\
\hline 24 & Zeca Pontes & 220 & River channel \\
\hline 25 & Macaca Pocu & 470 & River channel \\
\hline 26 & Btw Macaca Pocu \& Pagao & 1160 & Wide channel; low current \\
\hline 27 & Pagao & 420 & Wide channel; deep \\
\hline 28 & Btw Pagao \& Miratini & 1320 & Confluence of channels; low current \\
\hline 29 & Boca Miratini & 100 & Confluence of channels; with meeting of waters \\
\hline 30 & Btw Miratini \& Araue/ Curuca & 1660 & Confluence of channels; low current \\
\hline 31 & Araue/ Curuca & 150 & Confluence of channels; with meeting of waters \\
\hline 32 & Btw Araue/ Curuca \& Sapucaia & 400 & River channel; wide \\
\hline 33 & Sapucaia & 140 & Confluence of channels; with meeting of waters \\
\hline 34 & Btw Sapucaia \& Araca & 2010 & River channel \\
\hline 35 & Araca & 140 & Confluence of channels \\
\hline 36 & Btw Araca \& Sitio Sao Jose & 470 & River channel \\
\hline 37 & Sitio Sao Jose & 280 & River channel \\
\hline 38 & Btw Sitio Sao Jose \& Taracoa & 760 & River channel \\
\hline 39 & Taracoa & 220 & Confluence of channels; deep \\
\hline 40 & Btw Taracoa \& Vila Boca & 1450 & Confluence of channels; low current \\
\hline 41 & Vila Boca/ Boca Manhana & 570 & Wide channel; with meeting of waters \\
\hline 42 & Ressaca Boca & 1460 & Wide bay; low current \\
\hline 43 & Ressaca Tracaja & 660 & Bay; low current \\
\hline 44 & Ressaca Vila Alencar & 1050 & Wide bay \\
\hline 45 & Ressaca Clarindo & 810 & Bay; shallow \\
\hline 46 & Ressaca Japura/ Entrance Mam. & 1680 & Mamirauá channel joins the main river \\
\hline 47 & Praia Clarindo & 790 & Wide area; river beach \\
\hline
\end{tabular}




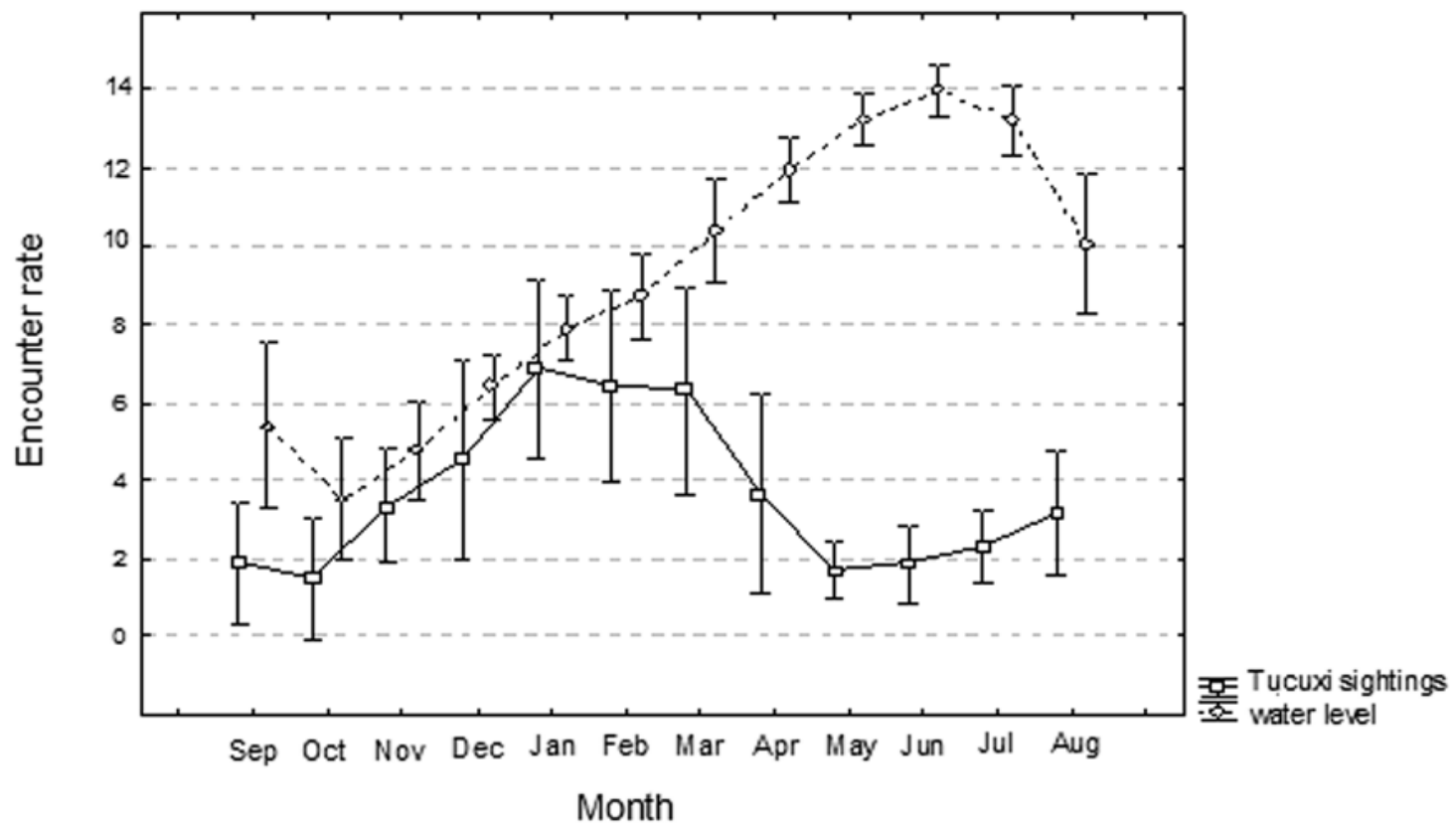

Figure 2. Encounter rate (mean number of tucuxi sightings per standardized monthly survey (i.e. Tucuxi sightings) (-口-) and river water level (m) ( ) per month, within the Mamirauá lake system. Data refer to standardized visual surveys within the study area ( $\mathrm{n}=84$ months). Vertical bars denote $95 \%$ confidence intervals.

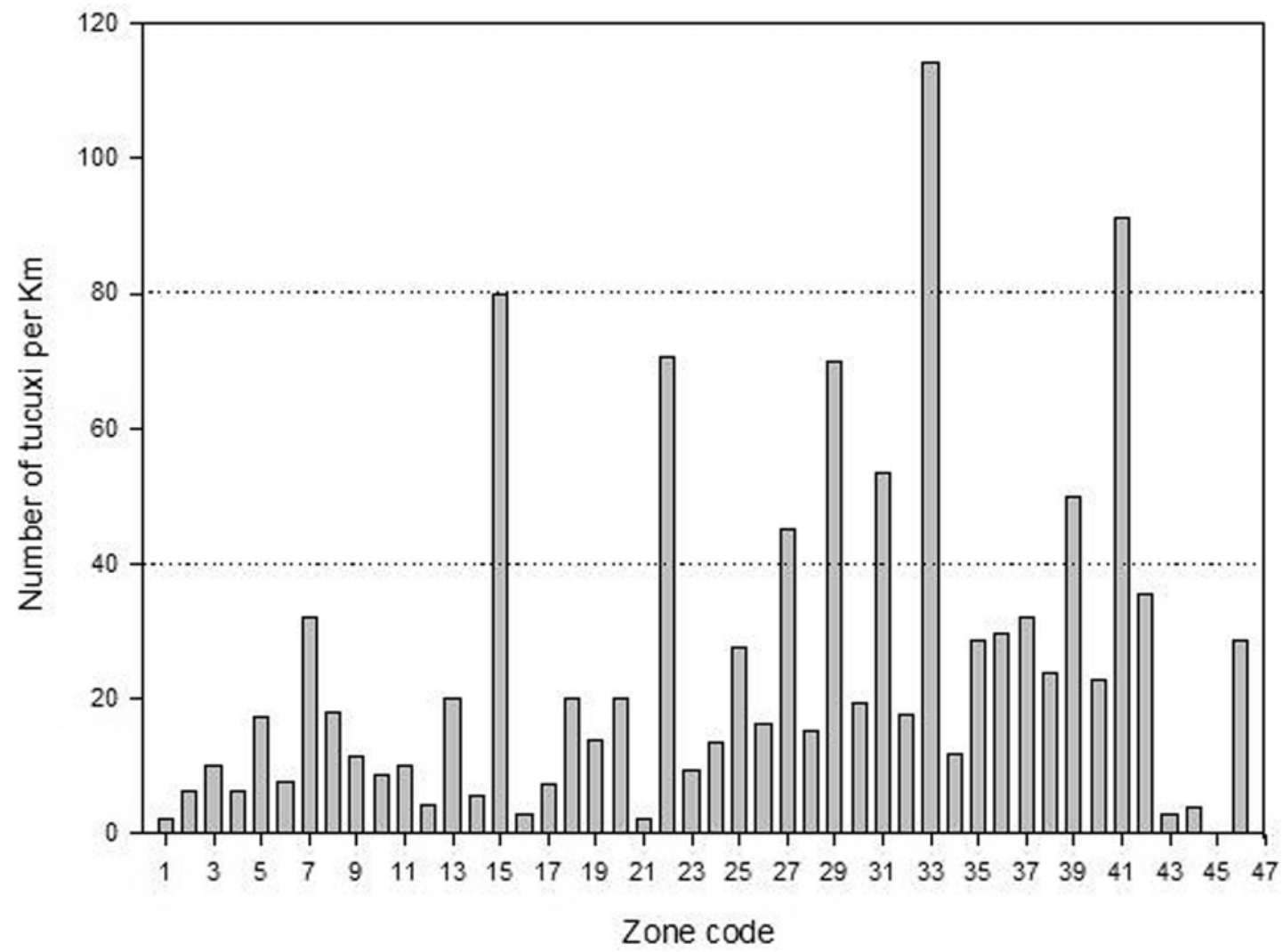

Figure 3. Number of tucuxi per length of water channel (tucuxis per km) within the Mamirauá system (1 - Mamirauá lake head to 46 - confluence of Mamirauá channel with Japurá River). Data from standardized visual surveys within the study area ( $\mathrm{n}=580$ sightings). 
Table 3. Tucuxi group size for each of the five systems considered in this study (Mamirauá, Amanã, Jacaré and Jarauá lakes, Japurá/ Solimões rivers). Data were recorded by all methods of data collection ( $\mathrm{n}=2677$ tucuxi groups).

\begin{tabular}{lcrrrr}
\hline \hline & & \multicolumn{5}{c}{ SYSTEM } \\
& MAMIRAUÁ & AMANÃ & JACARÉ & JARAUÁ & JAPURÁ/SOLIMÕES \\
\hline \hline mean & 3.328 & 3.897 & 2.357 & 3.458 & 3.139 \\
$\mathrm{SE}$ & 0.053 & 0.230 & 0.487 & 0.290 & 0.079 \\
mode & 2 & 2 & 2 & 2 & 2 \\
$\mathrm{n}$ & 1620 & 175 & 14 & 83 & 785 \\
$\mathrm{SD}$ & 2.125 & 2.911 & 1.823 & 2.643 & 2.217 \\
minimum & 1 & 1 & 1 & 1 & 1 \\
maximum & 30 & 20 & 8 & 13 & 20 \\
\hline \hline
\end{tabular}

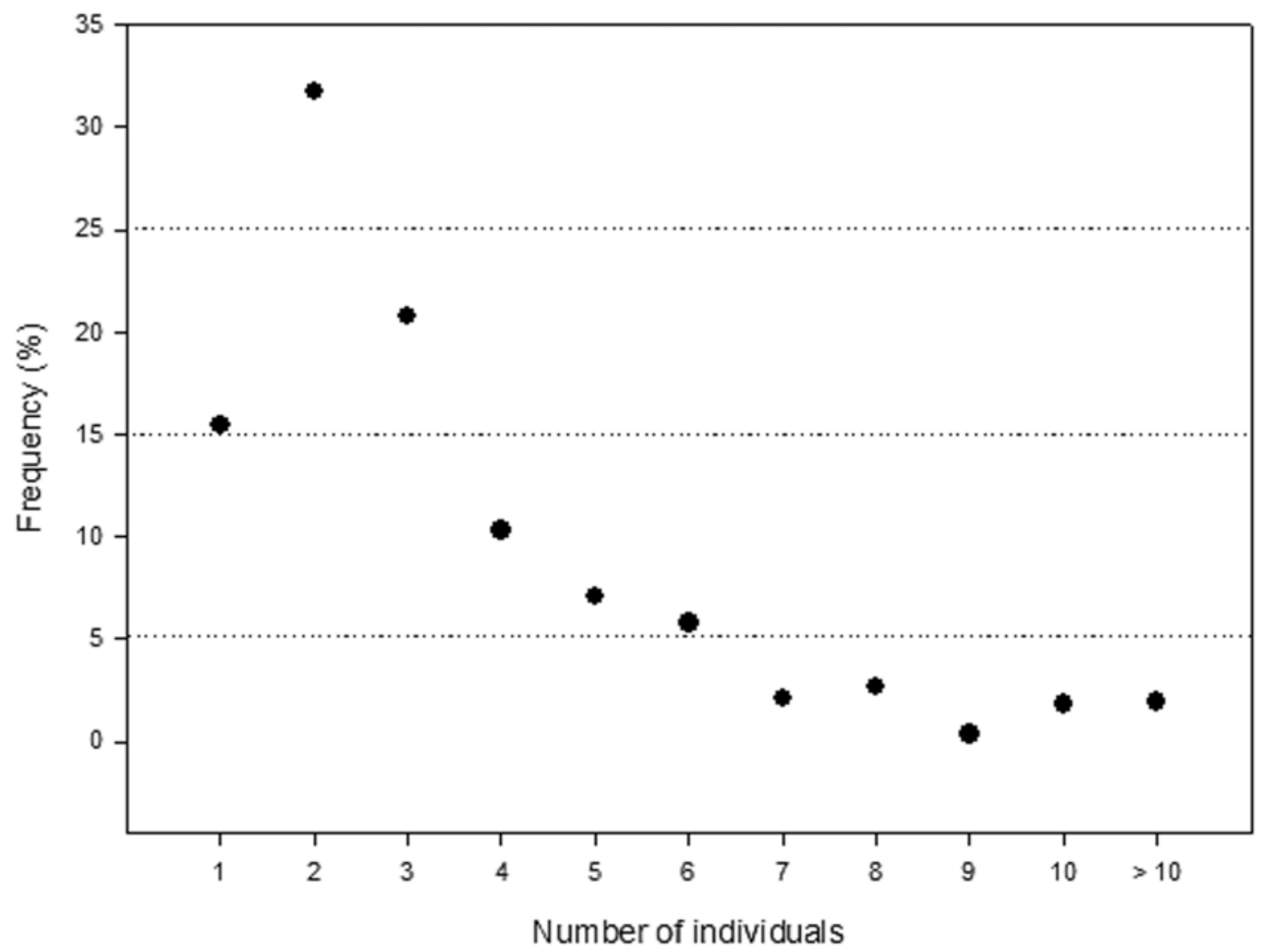

Figure 4. Relative frequency of tucuxi group sizes in and around the Mamirauá Reserve. Data are from all systems and methods of data collection ( $n=2677$ tucuxi groups).

The null hypothesis of group size equal distribution between systems across visual surveys (i), ii) and iii)) was rejected (Kruskal-Wallis: $\mathrm{H}_{4,2677}=20.059$, $\mathrm{df}=4, \mathrm{p}<0.001$ ), demonstrating very significant differences in tucuxi group size between systems. Overall, mean group size was lowest in Jacaré lake system $($ mean $=2.37, \mathrm{SE}=0.49$, mode $=2, \mathrm{n}=14$ ) and highest in Amanã (mean $=3.90, \mathrm{SE}=0.23$, mode $=2, \mathrm{n}=175$ ).

In Mamirauá system, the null hypothesis of similar mean group size between years, across visual surveys was rejected (Kruskal-Wallis: $\mathrm{H}_{9,87}=23.040, \mathrm{df}=9, \mathrm{p}=0.006$ ), showing significant differences in tucuxi mean group size among years, whereas no significant statistical differences among months were seen (Kruskal-Wallis: $\left.\mathrm{H}_{11,87}=9.333, \mathrm{df}=11, \mathrm{p}>0.05\right)$. In Mamirauá, mean group size per month ranged from 1.0 (October 2001) to 12.0 dolphins (November 1999) $(\mathrm{SE}=0.17$, mode $=2$, $\mathrm{n}=87$ ), with an overall mean group size of 3.30 dolphins $(\mathrm{SE}=0.17$, ode $=2, \mathrm{n}=87$ ). 


\section{Occurrence of calves and juveniles}

Tucuxi calves and juveniles were observed year-round within Mamirauá system, per standardized survey (ii), $\mathrm{n}=76$ ) (Figure 5).

Mean percentage of groups with one or more calves or juveniles sighted in a month averaged $2.9 \%$, and varied between zero in September and 7.2\% in May (SE $=6.58$, mode $=0, \mathrm{n}=83$ ).

\section{Discussion}

\section{Seasonal use of floodplain}

Tucuxis were present year-round within Mamirauá Sustainable Development Reserve, with differences in the seasonal use of floodplain.

The dramatic habitat change may explain why the lower numbers in tucuxi sightings were recorded in September and October months, when water level reaches its lowest around Mamirauá Reserve. Martin and da Silva (2004) also referred to the fact that botos (Inia geoffrensis, a sympatric Amazon dolphin) may avoid such shallow water bodies due to the risk of entrapment and death; this may well also be valid for tucuxis. The number of tucuxi sightings in May and June was quite low, a time when the water level peaks, creating additional habitats for tucuxis. Also, the water chemistry changes at this particular time that induce tucuxi prey movements. Floodplain water suffers from depleted oxygen levels at high water (Martin and da Silva, 2004), inducing most fish to leave the forest channel into the rivers (Crampton, 1999). Edwards and Schnell (2001) also reported the importance of environmental factors, such as water temperature and salinity, in the distribution and habitat use of riverine tucuxi in the Cayos Miskito Reserve, Nicaragua.

This suggests that fluctuating water levels also act indirectly on river dolphins' habitat use, by influencing the density, distribution and movements of their prey (fish) populations (Martin et al., 2004). Floodplain has a dense and diverse fish fauna which changes seasonally, and this attracts a similarly diverse community of piscivorous predators, including river dolphins. The Mamirauá Reserve and its surrounding rivers hold more than 300 species of fish (Crampton, 1999) and very high fish biomass densities (Barthem, 1999). In the Central Amazon, a total of 28 species of fish comprising 11 families were identified in stomachs of tucuxi (da Silva, 1983). Of the fish eaten, $82 \%$ were of pelagic habits and $75 \%$ form schools. The greatest diversity in diet occurred during the receding and lowest river levels as $60 \%$ of the prey species were unique to this season. In the dry

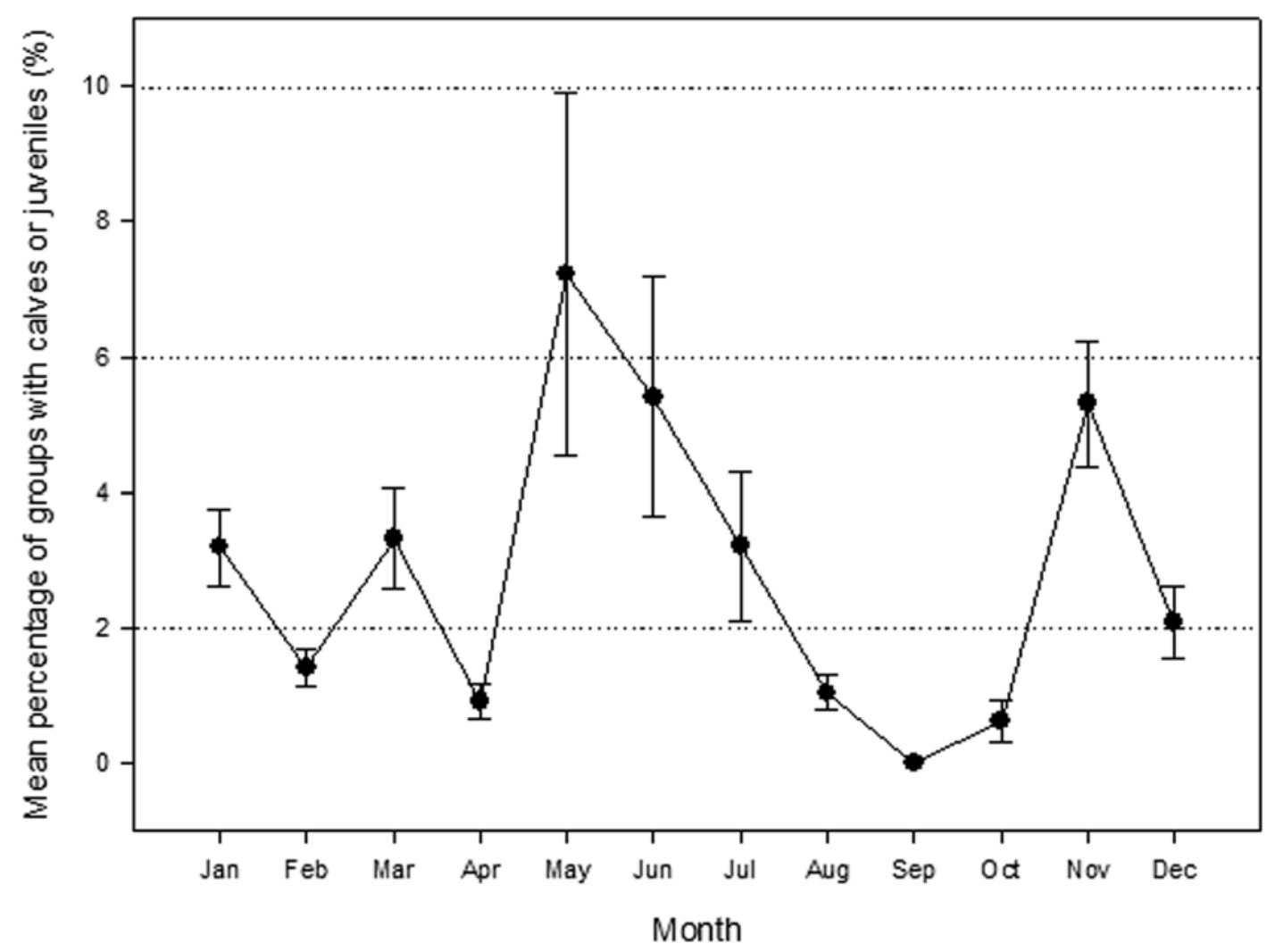

Figure 5. Mean percentage of groups with one or more calves or juveniles sighted from standardized monthly survey, within the Mamirauá Reserve ( $\mathrm{n}=83$ monthly records). Vertical bars denote \pm SE. 
season, fish become concentrated in the main water bodies, and thus are more vulnerable to dolphin predation. During the flood period, many of this fish species enter the floodplains to feed and the tucuxis cannot pursue them in these restricted habitats (da Silva and Best, 1994; 1996).

Taken together, the information presented in this study indicates the following seasonal pattern of use of floodplain by tucuxis within the Mamirauá system: 1) at lowest water level (September, October), tucuxis are present in very low numbers within Mamirauá, moving to the main channels where fish are concentrated and avoiding risk of entrapment in shallower water bodies; 2) as water level increases (November to April/May), additional habitats become available and tucuxis enter again the channels and lakes, increasing their occurrence in Mamirauá; 3) at highest water level (May and June), the number of tucuxis greatly decrease, following the fish density reduction in the open water bodies as well as oxygen depletion occurring at this time in the floodplain; and 4) with the decrease of water level (July and August) tucuxis move into the main rivers, following fish prey species that are forced to leave the flooded forest.

Timing will differ in different regions of the central Amazon, once the flood pulse takes months to pass along the river, but the sequence of events and their relation to the flood cycle is likely to be similar to the one described for Mamirauá (Martin and da Silva, 2004).

\section{Use of area}

Of the overall 46 zones within Mamirauá system, eight of them showed high tucuxi encounter rate, indicating tucuxi preference for given areas inside Mamirauá. These eight zones are all places where a small channel joins a larger one and where the water is likely to be deeper. They may be influenced by adjacent lakes, sometimes with "meeting of waters" (places at and downstream from confluences of black and white water channels, where contrasting waters run parallel to each other while slowly mixing), although with no significant water flow from confluences.

Magnusson et al. (1980) found tucuxi avoids areas of very high and very low turbulence congregating at the junctions of the rivers and channels, and da Silva and Best (1994) report this may be due in part to the abundance of fish and also to the fact that the turbulence disrupts fish schools making them more vulnerable to predation. Martin et al. (2004) evidenced confluences are chosen by fish migrating along the major rivers as they are areas of high productivity and offer underwater structure for refuge, and also found areas of confluences of waters together with the rare "meeting of waters" to be the most favored habitats for tucuxi within Mamirauá.

Tucuxis were seen scattered throughout $73 \%$ of the water channels but very seldom inside the Mamirauá Lake. The encounter rate of tucuxis within the innermost $10 \mathrm{~km}$ was quite low, possibly owing to the fact there are no water channels meeting and the water flow is reduced. This area is located at great distances from the main river, indicating tucuxis do not go far away from the river as do botos (Martin and da Silva, 2004). Henningsen et al. (1995) ${ }^{4}$ reported similar results in the Peruvian Amazon; tucuxi was only seen in the first $71 \%$ of the surveyed area, where the rivers were wider, deeper, and had less current. Also, Edwards and Schnell (2001) showed that distributions of tucuxi sightings were non-random, with a tendency towards clumping, indicating that tucuxi preferentially inhabit given areas of the Cayos Miskito Reserve.

\section{Group size}

Despite ranging from one to 30 dolphins, group size for tucuxi in and around Mamirauá system was usually of one to six individuals. Other authors have reported similar results. Magnusson et al. (1980) found 55\% of tucuxi groups to be of two or more individuals, $98 \%$ of the groups observed by Martin et al. (2004) were of groups of two to six, and groups of more than nine dolphins were reported to be seen on rare occasions by Best (1984) and Best and da Silva (1984).

Group size showed significant statistical differences among the five systems studied around Mamirauá Reserve. All the systems presented equal group size mode of 2.0 dolphins, but range and mean values differed. The fact that Amanã, Jacaré and Jarauá systems were only surveyed in some months and years led to different sample sizes that may explain the differences in group size recorded. These results may also be explained by specific habitat characteristics, or prey availability in each of the five systems studied, as each of them present different areas and physical characteristics (C. Faustino, pers. obs.).

In Mamirauá, mean tucuxi group size differed between years but not between months. The water level cycle has a similar pattern along the year, but shows some fluctuations between years. For a given month, the water level may be different, influencing tucuxi movements (V. da Silva, pers. obs.). Edwards and Schnell (2001) also recorded significantly variation in group size among years and no variation among months, in Nicaragua.

\footnotetext{
${ }^{4}$ Henningsen, T., Knickmeier, K., and Lotter, G. (1995) Behavioural ecology of the dolphins Inia geoffrensis and Sotalia fluviatilis in the upper region of the Amazon, Peru. Page 208-210 in Abstracts, IX Annual Conference of the European Cetacean Society, 9 - 11 February, Lugano, Switzerland.
} 


\section{Occurrence of calves and juveniles}

Tucuxi calves and juveniles were recorded year-round within Mamirauá system. Such records were very scarce though, and presented recurrent heterogeneous variance that made difficult to perform statistical analysis. Also, tucuxis are small and fast swimmers, and when in large groups, calves tend to stay inside the groups making their observation difficult.

Reproduction of tucuxi in the Amazon River basin is synchronous with the flood cycle, such that young are born during the low water season (October and November) when fish are most concentrated in the main water bodies and are thus more susceptible to predation (Goulding, 1980). The greater availability of fish at this time helps to offset the energy demands of lactation of the female (Best and da Silva, 1984; da Silva and Best, 1994; 1996). During this period tucuxis are hardly present within Mamirauá channels preferring the main river, both following prey migration and avoiding entrapment, as described earlier.

The number of tucuxi calves or juveniles sighted in and around Mamirauá system was small, thus further studies aiming to observe tucuxis would be important to confirm the seasonally of births in this region.

\section{Acknowledgements}

We thank the many people who contributed to the fieldwork of Projeto Boto on which this study is based. A special thanks to Patrícia Silva and Diogo Alagador for the help in statistical analysis. The article was improved due to useful comments and constructive criticism from Anthony R. Martin, the Editors, and two referees, Dr. Guido Parra and Dr. Marcos C. O. Santos, to whom we are most grateful. We gratefully acknowledge funding from the Darwin Initiative (DEFRA. UK), Overseas Development Administration of the UK Government (ODA, now DFID), World Conservation International (WCI/WCS), Conselho Nacional de Desenvolvimento Científico e Tecnológico (CNPq), Worldwide Fund for Nature (WWF), Instituto Nacional de Pesquisas da Amazônia (INPA), Instituto de Desenvolvimento Sustentável Mamirauá (IDSM) and Natural Environment Research Council (NERC).

\section{References}

Ayres, J.M. (1995) As matas de várzea do Mamirauá. Sociedade Civil Mamirauá, Rio de Janeiro, Brazil.

Barthem, R. (1999) A pesca comercial no médio Solimões e sua interação com a Reserva de Desenvolvimento Sustentável Mamirauá. Pages 72-107 in QueIroz, H.L. And Crampton, W.G.R. (Eds) Estratégias para o Manejo de Recursos Pesqueiros em Mamirauá. Sociedade Civil Mamirauá and CNPq, Brasília, Brazil.
BEST, R.C. (1984) Aquatic mammals and reptiles of the Amazon. Pages 371-412 in Sioli, H. (Ed) The Amazon. Limnology and Landscape Ecology of a Mighty Tropical River and its Basin. Leiden, The Netherlands.

Best, R.C. and DA Silva, V.M.F. (1984) Preliminary analysis of reproductive parameters of the Boutu, Inia geoffrensis, and the Tucuxi, Sotalia fluviatilis, in the Amazon River System. Report of the International Whaling Commission (special issue) 6: 361-369.

Caballero, S., Trujillo, F., Vianna, J.A., Barrios-Garrido, H., Montiel, M.G., Beltrán-Pedreros, S., Marmontel, M., Santos, M.C., Rossi-Santos, M., Santos, F.R. And BaKer, C.S. (2007) Taxonomic status of the genus Sotalia: Species level ranking for "tucuxi" (Sotalia fluviatilis) and "costero" (Sotalia guianensis) dolphins. Marine Mammal Science 23: 358-386.

CRAmpton, W.G.R. (1999) Os peixes da Reserva Mamirauá: diversidade e história natural na planície alagável da Amazônia. Pages 10-36 in QueIroz, H.L. AND CRAmpton, W.G.R. (Eds) Estratégias para Manejo de Recursos Pesqueiros em Mamirauá. Sociedade Civil Mamirauá/CNPq. Brasília, Brazil.

Cunha, H.A., DA Silva, V.M.F., Lailson-Brito JR, J., Santos, M.C.O., Flores, P.A.C., Martin, A.R., Azevedo, A.F., Fragoso, A.B.L., Zanelatto, R.C. and Solé-Cava, A.M. (2005) Riverine and marine ecotypes of Sotalia dolphins are different species. Marine Biology 148(2): 449-457.

DA Silva, V.M.F. (1983) Ecologia alimentar dos golfinhos da Amazónia. M.Sc. Thesis, Fundação Universidade do Amazonas (FUA)/Instituto Nacional de Pesquisas da Amazônia (INPA), Manaus, AM, Brazil. 112 pp.

DA SILVA, V.M. F. AND BEST, R.C. (1994) Tucuxi - Sotalia fluviatilis (Gervais) 1853. Pages 43-69 in Ridgway, S.H. And Harrison, R.J. (Eds) Handbook of Marine Mammals. Volume 5. The first book of dolphins. Academic Press, London, United Kingdom.

DA SILVA, V.M.F. AND BeST, R.C. (1996) Freshwater dolphin/ fisheries interaction in the Central Amazon (Brazil). Amazoniana XIV(1/2): 165-175.

DA Silva, V.M.F. AND Martin, A.R.M. (2000) A study of the boto, or Amazon river dolphin (Inia geoffrensis), in the Mamirauá Reserve, Brazil: operation and techniques. Pages 121-131 in Reeves, R.R., Smith, B.D. And Kasuya, T. (Eds) Biology and Conservation of Freshwater Cetaceans in Asia Occasional paper of the IUCN Species Survival Commission no. 23. IUCN, Gland, Switzerland.

EDWARDS, H.H. AND Schnell, G.D. (2001) Status and ecology of Sotalia fluviatilis in the Cayos Miskito Reserve, Nicaragua. Marine Mammal Science 17: 445-472.

Goulding, M. (1980) The Fishes and the Forest. University of California Press, Los Angeles, CA, USA.

IUCN (2004) 2004 IUCN Red List of Threatened Species. Available at www.iucnredlist.org. Downloaded on 16 March 2006.

KLINOWSKA, M. (1991) Dolphins, porpoises and whales of the world. The IUCN Red Data Book. IUCN - The World Conservation Union, Gland, Switzerland.

Magnusson, W.E., Best, R.C. And da Silva, V.M.F. (1980) Numbers and behaviour of Amazonian dolphins, Inia geoffrensis and Sotalia fluviatilis, in the Rio Solimões, Brazil. Aquatic Mammals 8: 27-32. 
Martin, A.R. (1990) Whales and Dolphins. Salamander Books Ltd, London and New York.

Martin, A.R., Da Silva, V.M.F., and Salmon, D.L. (2004) Riverine habitat preferences of botos (Inia geoffrensis) and tucuxis (Sotalia fluviatilis) in the Central Amazon. Marine Mammal Science 20: 189-200.

Martin, A.R. AND Da Silva, V.M.F. (2004) River dolphins and flooded forest: seasonal habitat use and sexual segregation of botos (Inia geoffrensis) in an extreme cetacean environment. Journal of Zoology (London) 263: 295-305.

Monteiro Filho, E.L.A., Monteiro, L.R. And dos Reis, S.F. (2002) Skull shape and size divergence in dolphins of the genus Sotalia: A tridimensional morphometric analysis. Journal of Mammalogy 83: 125-134. 